\title{
A cautionary note on the use of invertebrate trace fossils for correlation in the Triassic-Jurassic Fundy Group
}

\author{
Robert B. MacNaughton ${ }^{1 *}$ And Ron K. Pickerill ${ }^{2}$ \\ 1. Geological Survey of Canada, Natural Resources Canada, Calgary, Alberta T2L 2A7, Canada \\ 2. Department of Geology, University of New Brunswick, Fredericton, New Brunswick E3B 5A3, Canada \\ *Corresponding author <robert.macnaughton@nrcan.gc.ca>
}

Date received: 11 December 2009 Date accepted: 10 March 2010

\begin{abstract}
Red-bed strata generally considered to be of Triassic age are present in outcrop at Point Lepreau and St. Martins, New Brunswick. These successions preserve assemblages of invertebrate trace fossils that are similar to one another. Some authors have taken this as evidence that the successions are of similar age. However, all ichnotaxa that are common to the two successions (Ancorichnus cf. ancorichnus, Gordia marina, Palaeophycus isp., Planolites isp., and Skolithos isp.) are long-ranging forms that provide no useful age constraints in Triassic strata and cannot support the suggested correlation. Similarities between the ichnofaunas reflect the continental depositional setting of the two successions, in which trace-makers produced a Scoyenia ichnofacies. This does not falsify correlation between the Point Lepreau and St. Martins successions, which can be supported on other grounds. Instead, it reinforces the need for caution when using trace fossils for biostratigraphic purposes in much of the stratigraphic record.

\section{RÉSUMÉ}

Des couches de roches rouges dont on estime généralement qu'elles remontent au Trias affleurent à Point Lepreau et à St. Martins, au Nouveau-Brunswick. Ces suites pétrographiques préservent des assemblages de traces de fossiles d'invertébrés qui se ressemblent. Certains auteurs ont considéré qu'il s'agissait là d'une preuve que ces séquences sont plus ou moins du même âge. Toutefois, les traces de fossiles propres aux deux séquences (Ancorichnus cf. ancorichnus, Gordia marina, Palaeophycus isp., Planolites isp., et Skolithos isp.) sont des formes de longues durées qui n'offrent aucun indice utile de datation dans les strates du Trias; il est donc impossible de soutenir la corrélation alléguée. Les similitudes qui apparaissent dans les traces de fossiles d'invertébrés correspondent à un phénomène de sédimentation de deux séquences dans lesquelles les traces d'organismes ont produit un ichnofaciès de l'espèce Scoyenia. Par ailleurs, cela n'infirme en rien la corrélation entre les séquences de Point Lepreau et de St. Martins, laquelle peut être établie par d'autres indices. De fait, cela met encore plus en lumière le devoir de prudence lorsqu'il s'agit d'utiliser dans une large mesure des fossiles à l'état de traces à des fins d'analyse biostratigraphique pour l'établissement d'une fiche stratigraphique.
\end{abstract}

[Traduit par la redaction]

\section{INTRODUCTION}

Triassic strata in southern New Brunswick are part of the Fundy Group (Klein 1962) and crop out mainly as sea-cliff exposures at scattered localities along the northern margin of the Fundy Basin (e.g., Powers 1916; Klein 1962; Wade et al. 1996; Tanner 2000). Notably thick exposures are at Point Lepreau and St. Martins, where the strata historically assigned a Triassic age are more than $2.5 \mathrm{~km}$ thick (Nadon 1981). Correlation between these successions, and with those elsewhere, has been challenging due to a paucity of datable micro- or macrofossils. Thus, any viable source of chronostratigraphic control has been eagerly sought. Some authors have suggested that invertebrate trace fossils reported by MacNaughton (1990) can be used to correlate parts of the Lepreau and St. Martin's successions. These include an authoritative overview of Fundy Basin stratigraphy (Wade et al. 1996) and the Government of New Brunswick's online "Bedrock Lexicon of New Brunswick" (New Brunswick Department of Natural Resources 2010).

In certain contexts, trace fossils can be a valuable source of biostratigraphic data (e.g., Crimes 1970, 1975, 1987; Seilacher 1970, 2008; MacNaughton 2007). In this note, however, we argue that the trace fossil assemblages described by MacNaughton (1990) do not meet necessary prerequisites to 
be valid for stratigraphic correlation. The issue around the specific stratigraphic correlation is a relatively minor one and the correlation may be valid on other grounds. In discussing it, our goal is to emphasize the principles that underpin the viable use of trace fossils in biostratigraphy.

\section{STRATIGRAPHIC CONTEXT}

Red-bed strata at Point Lepreau belong to the Lepreau Formation (Wright and Clements 1943) and consist of conglomerate, breccia, sandstone, siltstone, and mudstone of alluvial-fan to braided-fluvial origin (Nadon 1981; MacNaughton and Pickerill 1995). They contain probable Pennsylvanian-aged lithoclasts (Alcock 1959), but no fossil evidence has been found for their age, so their assignment to the Triassic must be considered tentative. Red beds along the Lepreau River have been included in the Lepreau Formation by some workers and have yielded vertebrate trackways that Sarjeant and Stringer (1978) assigned to the ichnogenus Isocampe. Based on that assignment, those authors inferred a Late Triassic age for the Lepreau River red beds. Subsequently, palynology (Stringer and Burke 1985) and tectonic considerations (Park et al. 1994) indicated that these strata probably are of Carboniferous age. They have been assigned to the Balls Lake Formation (Carboniferous) by McLeod and Johnson (1998). We follow their assignment and exclude the Lepreau River red beds from the present discussion.

Around St. Martins three formations generally have been considered to be of Triassic age; they are summarized here from Nadon (1981) and Nadon and Middleton (1985). As at Point Lepreau, red beds are prevalent. The basal unit is the Honeycomb Point Formation, which is dominated by breccia, sandstone, and minor shale that record deposition mainly on alluvial fans. Overlying this is the Quaco Formation, a distinctive unit of pebble to cobble conglomerate with very wellrounded clasts. It was deposited in a large fluvial system. The succession is capped by the Echo Cove Formation, which contains breccia, conglomerate, sandstone, and shale. It records braided-fluvial and alluvial-fan depositional environments. Palynomorphs from the upper part of the Echo Cove Formation are of Carnian (early Late Triassic) age (Wade et al. 1996). Olsen et al. (2000; see also Olsen and Et-Touhami, 2008) referred to unpublished paleomagnetic data as evidence that the Honeycomb Point Formation is of Late Permian age but considered the two overlying formations to be Triassic.

Based on the palynological data, Wade et al. (1996) correlated the Triassic succession at St. Martins with the Wolfville Formation of Nova Scotia. They considered the Lepreau Formation probably to be equivalent to the lower Wolfville Formation. Alternatively, if the unpublished paleomagnetic data referred to by Olsen et al. (2000) are correct, then the Honeycomb Point Formation may be older than the Wolfville Formation. Olsen and Et-Touhami (2008) considered the Lepreau Formation to be a probable correlative of the Honeycomb Point Formation. Resolution of these issues is beyond the scope of the present note and the Lepreau and Honeycomb Point formations are likely to be correlative, whichever interpretation proves to be correct.

In their discussion of the Lepreau Formation, however, Wade et al. (1996, p. 209) argued that “...detailed ichnological studies suggest a correlation with the Late Triassic Honeycomb Point Formation further to the northeast (MacNaughton 1990)". This argument also appears in the entry for "Lepreau Formation" in the Government of New Brunswick's "Bedrock Lexicon of New Brunswick" (New Brunswick Department of Natural Resources 2010). It is this use of the trace-fossil assemblages for long-distance correlation that is problematic.

\section{COMPARISON OF ICHNOFAUNAS}

Although the Lepreau and Honeycomb Point formations may well be correlative, their invertebrate ichnofaunas provide no support for the correlation. The Triassic ichnofaunas at Point Lepreau and St. Martins are listed in Table 1. Data for Point Lepreau are for the entire Lepreau Formation at that locality and are taken from MacNaughton and Pickerill (1995), a work that slightly updated the observations of MacNaughton (1990). Data for St. Martins are mainly from the Honeycomb Point Formation, but also include material from the upper part of the Echo Cove Formation, and are taken from MacNaughton (1990). The Lepreau ichnofauna is markedly more diverse, although several of the ichnotaxa in that list were recorded only from single occurrences (MacNaughton 1990). Of the ichnotaxa present on both lists, Palaeophycus isp., Planolites isp., and cf. Skolithos isp. are common in both successions. Taenidium isp. is rare in both successions, whereas Ancorichnus cf. ancorichnus is of moderate abundance at Point Lepreau but rare at St. Martins. Gordia marina is known from one specimen at each locality.

MacNaughton (2007) has summarized three general situations where trace fossils are useful biostratigraphically, and the Triassic assemblages can be considered in light of these. First, an ichnotaxon can have a restricted stratigraphic range. An example of this is the ichnogenus Oldhamia. Its ichnospecies have characteristic radiating, flabellate, or dendritic morphologies and most are restricted to the Cambrian (e.g., Seilacher et al. 2005). By contrast, all ichnotaxa present in both the Lepreau Formation and the Honeycomb Point Formation are long-ranging forms, as indicated by the selected references. Palaeophycus isp., Planolites isp., and Skolithos isp. range from the latest Ediacaran (Crimes 1987) to the Pleistocene (D’Alessandro and Bromley 1986; Pemberton and Jones 1988). Taenidium isp. ranges from the Ordovician to the Pleistocene (Keighley and Pickerill 1994). Gordia marina has a range from at least the Cambrian (Crimes and Anderson, 1985) to the Eocene (Uchman 2001). The ichnospecies Ancorichnus ancorichnus is known mainly from the Jurassic of Greenland (Keighley and Pickerill 1994), but has also been reported from Cambrian-Ordovician strata in Argentina (Poiré et al. 2003). Note also that material studied by MacNaughton (1990) was 
Table 1. Comparison of Triassic ichnofaunas at Point Lepreau (Lepreau Formation) and St. Martins (Honeycomb Point and upper Echo Cove formations), New Brunswick. Dashed lines indicate ichnotaxa not observed at St. Martins. Data from MacNaughton (1990) and MacNaughton and Pickerill (1995).

\begin{tabular}{|c|c|}
\hline Point Lepreau & St. Martins \\
\hline Ancorichnus coronus & ----- \\
\hline Ancorichnus cf. ancorichnus & Ancorichnus cf. ancorichnus \\
\hline Aulichnites isp. & ----- \\
\hline Cruziana problematica & ---- \\
\hline Fuersichnus isp. & ----- \\
\hline Gordia marina & Gordia marina \\
\hline Palaeophycus striatus & ---- \\
\hline Palaeophycus isp. & Palaeophycus isp. \\
\hline Planolites isp. & Planolites isp. \\
\hline Rusophycus isp. & ---- \\
\hline Skolithos linearis & ---- \\
\hline cf. Skolithos isp. & cf. Skolithos isp. \\
\hline Taenidium isp. & Taenidium isp. \\
\hline "inclined meniscate burrows" & ---- \\
\hline "surface pit structures" & ----- \\
\hline
\end{tabular}

assigned only tentatively to this ichnospecies and may be a poorly preserved variant of another ichnospecies.

A second scenario in which trace fossils are helpful in biostratigraphy arises when the timing of first-appearance is known for one or more ichnotaxa that can be used to constrain the age of a trace-fossil assemblage. For example, first-appearance data are key elements of Ediacaran-Cambrian trace-fossil biozones (Crimes 1987; MacNaughton and Narbonne 1999). Even long-ranging ichnotaxa or low-diversity ichnofaunas can provide this kind of age control in an appropriate situation (e.g., Pickerill and Fyffe 1999). However, the probable Triassic age of the Lepreau and Honeycomb Point formations is well within the age ranges of the ichnotaxa that are common to both successions. First-appearance data cannot be applied.

Finally, a group of trace-making organisms may evolve relatively rapidly, with the resulting changes in the animals' behaviour or morphology being reflected in their trace fossils. Vertebrate tracks (Lockley 1998) and traces produced by trilobites or other arthropods (Seilacher 1970) are notable examples of this. But the ichnotaxa that are common to both the Lepreau and Honeycomb Point formations are long-ranging, conservative forms that change little, if at all, over their stratigraphic range. Also, most of the ichnotaxa can be identified only to the ichnogenus level, whereas trace-fossil biostratigraphy works best when material can be identified to the ichnospecies level (MacNaughton 2007).

What then explains the similarities between the two ichnofaunas? Most significant is that all strata in the two successions were deposited in continental environments-mainly fluvial and alluvial fan settings (Nadon 1981; Nadon and Middleton 1985). With this in mind, MacNaughton (1990; see also MacNaughton and Pickerill 1995) analyzed the ichnofaunas of both successions and found that they fit well within the Scoyenia ichnofacies (Seilacher 1967; MacEachern et al. 2007). Ichnofacies are distinctive groupings of trace fossils that recur in space and time and reflect the behavioural responses of organisms to the ecological limiting factors that characterize particular environments (e.g., MacEachern et al. 2007). Thus, similarities between the Lepreau and Honeycomb Point formation ichnofaunas are readily explained in terms of similar depositional environments, and the effects of their environmental limiting factors on burrowing organisms. They reflect similar depositional ages only inasmuch as they comprise ichnotaxa characteristic of many late Paleozoic and Mesozoic continental successions (see review by Buatois and Mángano 2007).

\section{CONCLUSIONS}

Triassic strata at Point Lepreau (Lepreau Formation) and St. Martins (Honeycomb Point and Echo Cove formations) contain broadly similar ichnofaunas. Ichnotaxa common to both successions are long-ranging forms that provide no useful biostratigraphic control and, contrary to some suggestions, cannot be used to correlate these formations. Similarities in ichnofaunal composition are more likely to reflect similar depositional environments. This does not falsify correlation between the Lepreau and Honeycomb Point formations, which 
is supported by regional geological considerations (Wade et al. 1996; Olsen and Et-Touhami, 2008), but does emphasize the need for caution when applying trace fossils to biostratigraphic problems (MacNaughton 2007).

\section{ACKNOWLEDGEMENTS}

We thank Peter Stringer for enjoyable conversations on Point Lepreau geology over many years. We are grateful for helpful comments and suggestions from the Geological Survey of Canada critical reader Godfrey Nowlan, journal reviewers Sören Jensen, and Murray Gingras, and journal editor Rob Fensome. This paper is a contribution to Geological Survey of Canada Project 07N (PaleoLab) and is Earth Sciences Sector contribution 20090315.

\section{REFERENCES}

Alcock, F.J. 1959. Musquash geology, Charlotte, Kings, and Saint John counties, New Brunswick. Geological Survey of Canada, Map 1084A, with descriptive notes, scale 1:63 360.

Buatois, L.A., and Mángano, M.G. 2007. Invertebrate ichnology of continental freshwater environments. In Trace fossils: concepts, problems, prospects. Edited by W. Miller III. Elsevier, Amsterdam, pp. 285-323.

Crimes, T.P. 1970. The significance of trace fossils in sedimentology, stratigraphy and palaeoecology with examples from Lower Palaeozoic strata. In Trace fossils. Edited by T.P. Crimes and J.C. Harper. Seel House Press, Liverpool, pp. 101-126.

Crimes, T.P. 1975. The stratigraphical significance of trace fossils. In The study of trace fossils. Edited by R.W. Frey. Springer-Verlag, New York, pp. 109-130.

Crimes, T.P. 1987. Trace fossils and correlation of late Precambrian and early Cambrian strata. Geological Magazine, 124, pp. 97-119. doi:10.1017/S0016756800015922

Crimes, T.P., and Anderson, M.M. 1985. Trace fossils from Late Precambrian-early Cambrian strata of southeastern Newfoundland (Canada): temporal and environmental implications. Journal of Paleontology, 59, pp. 310-343.

D’Alessandro, A., and Bromley, R.G. 1986. Trace fossils in Pleistocene sandy deposits from Gravina area, southern Italy. Rivista Italiana di Paleontologia e Stratigrafia, 92, pp. 67-102.

Keighley, D.G., and Pickerill, R.K. 1994. The ichnogenus Beaconites and its distinction from Ancorichnus and Taenidium. Palaeontology, 37, pp. 305-337.

Klein, G. deV. 1962. Triassic sedimentation, Maritime Provinces, Canada. Geological Society of America Bulletin, 73, pp. 1127-1146. doi:10.1130/0016-7606(1962)73[1127:TS MPC]2.0.CO;2

Lockley, M.G. 1998. The vertebrate track record. Nature, 396, pp. 429-432. doi:10.1038/24783

MacEachern, J.A., Pemberton, S.G., Gingras, M.K., and Bann,
K.L. 2007. The ichnofacies paradigm: a fifty-year retrospective. In Trace fossils: concepts, problems, prospects. Edited by W. Miller III. Elsevier, Amsterdam, pp. 52-77.

MacNaughton, R.B. 1990. Invertebrate ichnology of the Triassic of the Point Lepreau and St. Martins regions, southern New Brunswick. Unpublished B.Sc. thesis, University of New Brunswick, Fredericton, New Brunswick, Canada, $108 \mathrm{p}$.

MacNaughton, R.B. 2007. The application of trace fossils to biostratigraphy. In Trace fossils: concepts, problems, prospects. Edited by W. Miller III. Elsevier, Amsterdam, pp. 135-148.

MacNaughton, R.B., and Narbonne, G.M. 1999. Evolution and ecology of Neoproterozoic-Lower Cambrian trace fossils, NW Canada. Palaios, 14, pp. 97-115. doi:10.2307/3515367

MacNaughton, R.B., and Pickerill, R.K. 1995. Invertebrate ichnology of the nonmarine Lepreau Formation (Triassic), southern New Brunswick, eastern Canada. Journal of Paleontology, 69, pp. 160-171.

McLeod, M.J., and Johnson, S.G. 1998. Bedrock geological compilation of the Musquash area (NTS 21 G/01), Saint John, Charlotte, and Kings counties, New Brunswick. New Brunswick Department of Natural Resources and Energy, Minerals and Energy Division, Plate 98-22, scale 1:50 000.

Nadon, G.C. 1981. The stratigraphy and sedimentology of the Triassic at St. Martins and Lepreau, New Brunswick. Unpublished M.Sc. thesis, McMaster University, Hamilton, Ontario, Canada, 279 p.

Nadon, G.C., and Middleton, G.V. 1985. The stratigraphy and sedimentology of the Fundy Group (Triassic) of the St. Martins area, New Brunswick. Canadian Journal of Earth Sciences, 22, pp. 1183-1203.

New Brunswick Department of Natural Resources. 2010. Bedrock lexicon of New Brunswick Minerals and Energy Division. URL < http://www1.gnb.ca/0078/GeoscienceDatabase/Lexicon/qryFormationSummary-e.asp?Unitld=230>, February 2010.

Olsen, P. E., and Et-Touhami, M. 2008. Field Trip \#1: tropical to subtropical syntectonic sedimentation in the Permian to Jurassic Fundy rift basin, Atlantic Canada, in relation to the Moroccan conjugate margin. Central Atlantic Conjugate Margins Conference, Halifax, Nova Scotia, Canada, August 2008, $121 \mathrm{p}$.

Olsen, P. E., Kent, D. V., Fowell, S. J., Schlische, R. W., Withjack, M. O., and LeTourneau, P. M. 2000. Implications of a comparison of the stratigraphy and depositional environments of the Argana (Morocco) and Fundy (Nova Scotia, Canada) Permian-Jurassic basins. In Le Permien et le Trias du Maroc: actes de la premièr réunion du Groupe Marocain du Permien et du Trias. Edited by M. Oujidi and M. Et-Touhami. Hilal Impression, Oujda, pp. 165-183.

Park, A.F., Williams, P.F., Ralser, S., and Léger, A. 1994. Geometry and kinematics of a major crustal shear zone segment in the Appalachians of southern New Brunswick. Canadian Journal of Earth Sciences, 31, pp. 1523-1535.

Pemberton, S.G., and Jones, B. 1988. Ichnology of the Pleis- 
tocene Ironshore Formation, Grand Cayman Island, British West Indies. Journal of Paleontology, 62, pp. 495-505.

Pickerill, R.K., and Fyffe, L.R. 1999. The stratigraphic significance of trace fossils from the Lower Paleozoic Baskahegan Lake Formation near Woodstock, west-central New Brunswick. Atlantic Geology, 35, pp. 205-214.

Poiré, D.G., Spalletti, L.A., aand Del Valle, A. 2003. The Cambrian-Ordovician siliciclastic platform of the Balcarce Formation (Tandilia System, Argentina): facies, trace fossils, palaeoenvironments and sequence stratigraphy. Geologica Acta, 1, pp. 41-60.

Powers, S. 1916. The Acadian Triassic. Journal of Geology, 24, pp. 1-26, 105-122, 254-268. doi:10.1086/622299

Sarjeant, W.A.S., and Stringer, P. 1978. Triassic reptile tracks in the Lepreau Formation, southern New Brunswick, Canada. Canadian Journal of Earth Sciences, 15, pp. 594-602.

Seilacher, A. 1967. Bathymetry of trace fossils. Marine Geology, 5, pp. 413-428.

Seilacher, A. 1970. Cruziana stratigraphy of "non-fossiliferous" Palaeozoic sandstones. In Trace fossils. Edited by T.P. Crimes and J.C. Harper. Seel House Press, Liverpool, pp. 447-476. doi:10.1016/0025-3227(67)90051-5

Seilacher, A. 2008. Principles of ichnostratigraphy. In Sediment-organism interactions: a multifaceted ichnology. Edited by R.G. Bromley, L.A. Buatois, G. Mángano, J.F. Genise, and R.N. Melchor. SEPM Special Publication 88, pp. 53-56.
Seilacher, A., Buatois, L.A., and Mángano, M.G. 2005. Trace fossils in the Ediacaran-Cambrian transition: behavioral diversification, ecological turnover and environmental shift. Palaeogeography, Palaeoclimatology, Palaeoecology, 227, pp. 323-356. doi:10.1016/j.palaeo.2005.06.003

Stringer, P., and Burke, K.B.S. 1985. Structure in southwest New Brunswick. Geological Association of Canada/Mineralogical Association of Canada, Field Trip Guidebook, Excursion 9, $34 \mathrm{p}$.

Tanner, L.H. 2000. Triassic-Jurassic lacustrine deposition in the Fundy Rift Basin, eastern Canada. In Lake basins through space and time. Edited by E.H. Gierlowski-Kordesch and K.R. Kelts. AAPG Studies in Geology 46, pp. 159-166.

Uchman, A. 2001. Eocene flysch trace fossils from the Hecho Group of the Pyrenees, northern Spain. Beringeria, 28, pp. 3-41.

Wade, J.A., Brown, D.E., Traverse, A., and Fensome, R.A. 1996. The Triassic-Jurassic Fundy Basin, eastern Canada: regional setting, stratigraphy and hydrocarbon potential. Atlantic Geology, 32, pp. 189-231.

Wright, W.J., and Clements, C.S. 1943. Coal deposits of the Lepreau-Musquash district, New Brunswick. Acadian Naturalist, 1, pp. 5-27.

Editorial responsibility: Robert A. Fensome 